\title{
Effective Resource Utilization: A Better Approach to Teaching and Learning of Physics
}

Okeke Sunday .0

\author{
Okoye, Nestor .E \\ Department of Physics \\ Federal College of Education (Technical) \\ Umunze-Anambra State,Nigeria
}

\section{Doi:10.5901/ajis.2013.v2n6p35}

\begin{abstract}
The teaching/learning of science has been advocated for sustainable national development. Physics is an integral part of science which requires special approach for effective understanding. For effective understanding of physics concepts, the application and effective use of resources has been identified as a better approach. The resources if well utilized, increase the achievement level of the students and also engender positive changes. This paper X-rayed how the classes of resources identified here could be harnessed by physics teachers and students for the purpose of educational training to facilitate and encourage the acquisition of knowledge competence, skill and know-how. Constraints to effective resources utilization were also identified and analyzed.
\end{abstract}

\section{Introduction}

A resource is anything which can be used to achieve the goals and objectives of an organization. Teaching and learning resources according to Awolola (2000) are those human and materials inputs necessary for achieving the objectives of concepts to be taught. It is the sum total of everything used directly or indirectly for the purpose of educational training to facilitate or encourage the acquisition of knowledge competence, skill and know-how (Akinsola, 2000). In the teaching and learning context, resources or teaching aids or materials as they may be called can be classified into five categories (Adobe, 2000). They are:

- People: teachers, students, etc.

- Materials: textbooks, skeleton etc

- Tools and equipment: chalkboard, slide projectors, etc.

- Settings: school building, library

- Activities: games, field trips.

Federal Ministry of Education (FME) (2001) revealed that teaching in higher institutions is mainly based on lecture methods, thus limiting the use of instructional materials to mainly chalk and chalkboard. Physics teachers and students acknowledge the fact that those instructional materials that can be used to provide students with practical experiences in learning physics are rarely used during physics lessons. Accusing fingers point at the following:

$>$ Low teacher competence in the area of effective resource utilizations.

$>$ Failure to appreciate the importance of using such resources in promoting and understanding of physics concepts.

$>$ Insufficient awareness of types of resources for use in teaching different physics content areas 
Limited ability to use instructional materials.

It could be seen here that the accusing fingers invariably point at the teachers. Teachers are always regarded as possessors of knowledge while students are empty urns to whom the knowledge should be poured.

\section{Why Utilize the Resources Effectively?}

The extent of acquisition of knowledge, skills and attitudes relevant to life altogether depends on the quality of teaching/learning activities that teachers provide for learners to interact with and the quality of the interaction; factors largely dependent on the nature and the quality of resources at the teacher's disposal. Such resources, if well used, increase the achievement level of the students and also engender positive changes. No wonder Biggs (1994) stated that students can change their approaches to learning according to demands of each situation; the extent to which the changes is affected by each student's disposition and the events in the class.

These events include the resources provided by the physics teacher and how they are effectively selected during instruction delivery. Adequate and appropriately used resources by a physics teacher enable physics students to:

$>$ Develop positive attitude and healthy self concept because successes in carrying out the activities make physics students believe they can do it.

$>$ Enjoy and appreciate their subjects of study

$>$ Develop understanding and judgment

$>$ Develop functional knowledge and manipulative skills.

\section{How to Effectively Utilize Resources}

Designing physics teaching and learning process on the principle of linking and undertaken physics activity to abstract concepts is the cornerstone of effective resource utilization. Okeke (2008) decleared that variability in the choice of teachers methodologies/materials is advocated during the design so as to accommodate varied interest of physics learners, knowing fully well that the most important resource in the classroom is the learner.

The designing principle involves;

- Analyzing the students

- Selecting the objectives

- Selecting the materials

- Utilizing the materials

- Requiring students participation

- Evaluating the students so as to get feedback.

Teaching/learning physics is an activity whose success is determined by a host of factors, among them are the nature and availability of necessary resources and also the teacher factor which is probably the most critical. Any physics teacher who intends to realize optimum result from the use of resources has to appreciate the principle of selecting appropriate resources. The teacher should look for the best fit between the concept to be taught and the strategies to teach them.

The following are hints on how to select physics resources;

1. The physics teacher should have comprehensive knowledge and understanding of:

- The physics content for which the resource is being selected, where in doubt one should consult. The aphorism that two good heads are better than one good head becomes more relevant in the field of education particularly in teaching.

- The teaching - learning process so as to appreciate what is expected and when it is expected. Akubue (1991) noted that the lack of familiarity with the basic concepts and 
principles of classroom management constitutes a major hindrance to level of preparedness, quality of environment, subject organization, and social climate of learning as well as other behaviour-related problems surrounding content delivery.

The Resources Selected should:

- Be relevant to the stated objectives: The primary purpose of teaching-learning is for the attainment of pre-specified instructional objectives. Teachers are expected to be aware that the nature of instructional objectives (cognitive, affective or psychomotor) will determine the resource to be selected. For instance, if the objective under consideration is in the cognitive domain and borders on the acquisition of facts. Principles, knowledge, then textbook or radio may be adequate as a resource material.

- Reflect individual differences/appeal to learners characteristics: The age, level, interest, background, learning style etc. of the learner often vary and hence resources to be selected should relate to the individual differences of the learner. Ogunranti et al (1982) noted that the learning style of learners is a potent factor in their ultimate achievement. The teacher is therefore expected to ensure that the resource being selected will be appropriate to the age, level, interest and background of the learner. This is necessary because learners as human beings learn through various senses and hence the resources/materials that appeal to more than one sense should essentially be selected.

- Not be too expensive: Finance is one of the major problems facing schools. Therefore, the teacher must consider the cost or financial implications of the resource to be selected for classroom utilization. Where possible, the resource should not be expensive. Where expensive, however, the physics teacher resorts to improvisation. There are a lot of resources in the local neigbourhood which innovative teacher can exploit for the benefit of their students. In the course of the exploitation, students are involved. Such improvisation is a way of increasing inquiry, curiosity, creativity and productive application of intellect.

- Be easy to maintain and replace when need arises: Resources for instruction have characteristics. The characteristics of various resources to be selected and utilized should therefore be known by the teacher and adequate consideration given to whether the resources for using them are flexible, easy to manipulate or operate, repair and maintain when the need arises. This is sequel to the fact that some of these resources are portable and durable while some others have easily available accessories. Therefore, the teacher ought to put into consideration all these in trying to select resources for class use.

- Be appropriate to the skills to be taught: Acquisition of skill especially the science process skills is at the heart of physics teaching and learning. Chukwuemeka and Aneale (2008) describes science process skill as the generalization and transferable intellectual and physical capabilities needed to learn concepts and broad principles used in making valid inductive inference. Some of these process skills include: observation, inquiry, organization, inferring controlling variable etc. Hence, in order to focus students attention and sustain their interest thereby acquiring the skill of observation for instance in a learning session, the teacher can use such resources as film strip projector, slide projector, 8 and $16 \mathrm{~mm}$ cinematographic projector and so on.

Further, resources such as laboratory equipment may be used to provide the means of discovering ideas and relationships thereby acquiring such skills as inference i.e inferring.

- Having a wide range of practicability: Before selecting any resource, consideration should be given on the number of teaching/learning situations to which the resource can be applied. This is because it is more economical to buy a material which has dual usage than to buy one that can be applied in a single learning situation. 


\section{Constrains/Challenges to Effective Resource Utilization}

The following constraints/challenges to effective resource utilization can be identified.

> Time Allocation on the Time-Table: Physics constitutes just a part of school curriculum and to accommodate other subjects, the time table stipulates the duration for each subject. In a study carried out by Agusiobo (2002) and Obi, Okoli and Umeojiako (2001) it was identified that the contact hour for the teaching and learning of physics in our schools is grossly inadequate. In order to cover the curriculum content, however, most teachers rush through the content using lecture method. This does not give room for exposing students to enough practical work nor does it allow for effective utilization of resources.

$>$ Poor Staffing: Most institutions are faced not only with shortage of physics educators in number but also in quality and experience. Okoye (2010) observed that physics educators that should take up the responsibility of teaching physics students are grossly inadequate, and described it as disturbing and regrettable. The inadequacy of qualified and experienced teaching staff has made it possible that teachers with little or no pedagogy and relevant experience are assigned to teach practical courses as well as other courses that require special skill and equipment. As a result of this, some themes or topics that require special skills in handling are skipped. Where they are taught the contents are usually delivered on the peripheral.

> Inadequate power supply: Most of our rural areas do not have access to electricity. Hence, the teaching of some skills using equipment that are electricity operated become difficult. In the urban areas where electricity may be available, the incessant electric power outages as well as epileptic power supply becomes another problem of great concern.

> Lack of opportunities for inservice training/refresher course for serving physics teachers: Opportunities are not always given to teachers and technicians for refresher courses on the application and use of new equipment and materials. Such refresher courses will enable physics teachers and technicians to update their knowledge periodically in the light of new research findings and resource development. This way they will remain relevant in the field.

\section{Summary/Conclusion}

Poor academic achievement in physics has been attributed to many factors among which teacher's strategy and effective utilization of resources were considered as important factors. This implies that the mastery of physics concepts might not be fully achieved without effective utilization of resource/materials. It is therefore paramount that physics teachers employ and utilize resources effectively to enhance teaching and learning of physics. Resources when effectively utilized brings about effectiveness and efficiency in the teaching-learning process and invariably promote and enhance the attainment of instructional objectives. Since educational resources play vital roles in the teaching-learning process, teachers should essentially be familiar with the principle of designing and producing, selecting and utilizing education resources.

\section{References}

Adobe, I.A. (1998). Basic Instructional Technology. Unpublished Handbook, Teacher Education Series PP. 6-7.

Agusiobo, N.N. (2002). Constraints to Effective Implementation of Senior Secondary School Physics Curriculum in Orumba South Local Government Area. J ournal of Technical Education Research and Development J OPTERD (II). 
Akinsola, M.K. (2000). Enriching STM Education: Effect of Resource Utilization on Students' Achievement in Geometry. Proceeding of $41^{\text {st }}$ Annual Conference of STAN.

Akuebue, A.U. (1991). Classroom Organization and Management: A 5-Point Strategy. Ibadan. Wisdom Publishers Ltd.

Awolola, J.B. (2000). Community Resource Utilization in the Teaching of Integrated Science. A Paper Presented at the National Workshop on Integrated Science, May 15-20.

Biggs, J. (1994). Approaches to Learning: Nature and Measurement. In T. Husein and T.N. Postlewaite (eds). The International Encyclopedia of Education (2 ${ }^{\text {nd }}$ Edition). (1) 319-322. Oxford Pergamon.

Chukwuemeka, P.C. \& Aneale, N.P.(2008). The Effect of Mode of Presentation of Material Resources on Acquisition of Science Process Skills among Science Pupils: Implication for Primary Science Curriculum Delivery. In Udofia (ed.) $49^{\text {th }}$ Annual STAN Conference Proceedings.

Obi, J.U; Okoli, L.U. \& Umeojiako, C. (2001). Problems of Teaching Practical Physics in Secondary Schools in Aguata Local Government Area. Unpublished NCE Thesis F.C.E (T), Umunze.

Ogunranti, A. et al (1982). Educational Technology: ACE Series. Ibadan, Institute of Education, University of Ibdan. Heinemann.

Okeke, S.O. (2008). Factors Affecting Teacher Effectiveness in the Teaching and Learning of Physics in Secondary Schools in Anambra State. J ournal of Education for Professional Growth. 4 (1).

Okoye, N.E. (2010). Physics Education: The Foundation for Achieving Universal Primary Education and Eradication of Extreme Poverty for Millennium Development Goals. In Ogbuagu, J.0. \& Nwamaradi, A.T (eds). Skills Development in Science/Technology Education for the Millennium Development Goals. 
